\title{
TOIMINTAKYVYN MITTAAMINEN KUNTOUTTAVASSA LUONTOLÄHTÖISESSÄ TOIMINNASSA
}

\section{Katsaus Hoivafarmi-hankkeessa sovellettuihin toimintakykymittareihin}

Luontolähtöisten hyvinvointipalvelujen kehittäminen on kansainvälisten esimerkkien myötä vauhdittunut viime vuosina Suomen hoivaja kuntoutuspalveluissa. Palveluiden kehittämisen rinnalla on noussut esiin tarve seurata palveluiden tuottamia hyvinvointivaikutuksia ja luontolähtöisellä toiminnalla aikaan saatavia muutoksia asiakkaiden toimintakyvyssä. Toimintaa on kehitetty maassamme muun muassa luonnon ja maaseudun hyvinvointivaikutuksiin perustuvaa palvelutoimintaa edistävän valtakunnallisen Green Care Finland ry:n sekä erilaisten hankkeiden avulla. Vuoropuhelu kehittäjien kesken on lisääntynyt sekä Suomessa että kansainvälisesti. Luonnon hyvinvointivaikutuksiin liittyvä tutkimus on monitieteistä, ja näin on saatu ymmärrystä hyvinvointivaikutusten moninäkökulmaisuuteen ja kokonaisvaltaisuuteen.

Green care näyttää vakiinnuttavan Suomessa asemaansa tavoitteellista ja ammatillista luontolähtöistä toimintaa kuvaavana käsitteenä. Yksi tapa jäsentää green care -palveluita on jaottelu luontolähtöiseen virkistykseen, hyvinvointimatkailuun sekä harrastusja kasvatustoimintaan pohjautuviin luontovoiman palveluihin sekä julkisen sektorin järjestämisvastuulle kuuluviin luontoympäristöjä ja -elementtejä hyödyntäviin ammatillisen hoivan, hoidon ja kuntoutuksen luontohoivapalveluihin (Soini 2014).

Etelä-Savossa on Kaakkois-Suomen ammattikorkeakoulun hallinnoimien tutkimusja kehittämishankkeiden muodossa kehitetty usean vuoden ajan luontolähtöisiä hyvinvointipalveluja. Viimeisimpänä kehittämisen kohteena on ollut maatiloilla tarjottava kuntouttava luontolähtöinen toiminta. Kehittämistyötä toteutettiin Euroopan sosiaalirahaston osarahoittamassa Hoivafarmi-hankkeessa vuosina 2014-2016. Yksi osa kehittämistyötä oli toimintakykymittarin laatiminen maatilatoimintaan osallistuvien asiakkaiden toimintakyvyn seurantaan. Asiakkaina oli mielenterveyskuntoutujia sekä kehitysvammaisia. Tässä katsauksessa kuvataan Hoivafarmi-hankkeessa asiakkaiden toimintakyvyn seurantaan sovellettuja toimintakykymittareita.

\section{Kuntouttavan Iuontolähtöisen toiminnan kehittäminen ja vaikutusten mittaaminen}

Sosiaali-, terveys- ja laajemminkin hyvinvointipalvelualalla esiintyy kiinnostusta luontolähtöisten palvelujen kehittämiseen ja tuottamiseen. Green Care Finland ry:n ylläpitämään ja julkaisemaan palveluntuottajapor- 
taaliin oli alkuvuoden 2017 tietojen mukaan ilmoittautunut 158 green care -palveluntuottajaa eri puolelta maata. Lisäksi lukuisat maassamme käynnissä olevat alan kehittämishankkeet ovat osoitus luontolähtöiseen toimintaan kohdistuvasta kiinnostuksesta.

Green care -toimintaa ja sen arvostamista vahvistaa ammatillista luontolähtöistä toimintaa toteuttaville alan yrittäjille ja muille palveluntuottajille suunnattu valtakunnallinen green care -laatumerkki, jonka haku avautui vuoden 2017 alussa ja jota hallinnoi Green Care Finland ry (Valtakunnallinen Green Care Koordinaatiohanke 2017). Laatumerkin saadakseen palveluntuottajan tulee osoittaa tarjoamansa luontolähtöisen palvelun lähtökohdat, tavoitteet, sisällöt ja keskeiset green care -laadunhallinnan välineet, kuten turvallisuus- ja omavalvontasuunnitelma.

Luontohoivan alueelle sijoittuvat kuntoutuspalvelut voivat olla hyvin moninaisia asiakkaiden tuen tarpeista, kuntoutuksen tavoitteista sekä palvelussa hyödynnettävistä luontoympäristöistä ja -elementeistä riippuen. Esimerkkejä kuntouttavasta luontolähtöisestä toiminnasta ovat erilaiset eläinavusteiset terapiat (esimerkiksi ratsastusterapia), hoivamaatilat, jotka toimivat kuntouttavina asumisyhteisöinä usein paljon ohjausta ja tukea tarvitseville nuorille ja aikuisille, ohjattu luontolähtöinen työ- ja päivätoiminta maatiloilla, sosiaalinen ja terapeuttinen puutarhatoiminta, puutarhaterapia tai vaikkapa ammatillinen metsäympäristöjen hyödyntäminen päihdetyössä (ks. Sámi Soster 2017).

Luontolähtöisten palvelujen kehittämisen rinnalla keskeinen kysymys liittyy palvelun vaikuttavuuteen. Käytännössä tämä näkyy green care -palveluntuottajien tarpeena löytää sellaisia seurannan ja arvioinnin työkaluja ja menetelmiä, jotka olisivat helposti sovellettavissa asiakastyön arjessa asiakkaiden toimintakyvyn ja siinä tapahtuvien muutosten seurantaan. Palvelunostajia, kuten kuntia tai sairaanhoitopiirejä, voi puolestaan kiinnostaa näyttö luontolähtöisen toiminnan vaikutuksista asiakkaan hyvinvointiin ja toimintaky- kyyn. Kyse on kilpailutaloudellisten tekijöiden vahvistumisesta julkisessa palvelujärjestelmässä ja kasvaneista vaatimuksista saada sosiaali- ja terveyspalveluilta vastinetta niihin sijoitetulle julkiselle rahoitukselle (value for money -ajattelu, ks. Vedung 2003). Toisaalta tieto palvelun asiakasvaikutuksista voi auttaa tunnistamaan toimivia käytäntöjä ja arvioimaan palvelun kykyä tuottaa hyvinvointia ja vastata asiakkaan kuntoutustarpeisiin.

Toimintakyvyn arvioinnissa voidaan soveltaa jo kehitettyjä ja testattuja toimintakykymittareita ja/tai kulloisenkin palvelun ja asiakasryhmän toimintakykyä huomioivia spesifejä ad hoc -mittareita ${ }^{1}$. Katsaus luontolähtöisten interventioiden vaikutusten arviointeihin kansainvälisissä tutkimuksissa osoittaa, että arvioinneissa on huomioitu fyysisiin, psyykkisiin, sosiaalisiin sekä kognitiivisiin taitoihin liittyviä toimintakyvyn osa-alueita, ja hyvinvointitietoa on kerätty määrällistä tietoa tuottavien strukturoitujen kyselyjen lisäksi myös laadullisilla aineistonkeruumenetelmillä. (Hirvonen 2014, 16-23.)

Green Care Finland ry:n vuonna 2015 järjestämä luontolähtöisen toiminnan asiakasvaikutusten mittaamiseen liittyvä kansallinen seminaari lisäsi osaltaan tietoa viimeaikaisista luonnon hyvinvointivaikutuksiin liittyvistä tutkimushankkeista maassamme. Tiedonkeruu luontolähtöisen toiminnan asiakasvaikutuksista näyttää usein perustuvan asiakkaan ja ohjaajan tekemään havainnointiin. Joissakin luontolähtöisen toiminnan tutkimus- ja kehittämishankkeissa on toteutettu myös fysiologisia mittauksia. (Hirvonen \& Uosukainen 2015.)

Luontolähtöisen toiminnan - puhumattakaan rajatummin kuntouttavan luontolähtöisen toiminnan - asiakasvaikutusten mittaamisen käytännöt vaihtelevat suuresti. Nykytilannetta kuvannee hyvin se, että luontolähtöisen toiminnan vaikutuksia asiakkaan toimintakykyyn arvioidaan vaihtelevasti, ja seurannan ja arvioinnin tueksi laaditaan, testataan ja otetaan käyttöön tapauskohtaisesti erilaisia toimintakyvyn seurannan mittareita. Kuntouttavan luontolähtöisen toiminnan näkökulmasta

\footnotetext{
' Tiettyyn tarkoitukseen ja tilanteeseen sekä varta vasten tietyn tutkimusasetelman tarpeisiin räätälöity mittari.
} 
laadittua spesifiä toimintakykymittaria ei ole saatavilla. Ongelmia sopivan mittarin laadintaan tuottaakin eri asiakasryhmien erilaisuus. Kuntouttavaa luontolähtöistä toimintaa voidaan toteuttaa täysin itsenäisesti toimivien asiakkaiden parissa ja toisaalta myös laitoksissa, joissa kohderyhmänä voivat olla autettavat henkilöt, kuten muistisairaat vanhukset.

\section{Toimintakyvyn mittaaminen Hoivafarmi-hankkeessa}

Hoivafarmi-hankkeessa kehitettiin maatiloilla toteutettavaa erityisryhmien päivä- ja työtoimintaa yhteistyössä maatilojen sekä sosiaalija terveysalan palveluyksiköiden kanssa. Maatila-avusteisten kuntouttavien luontolähtöisten palvelujen käyttöön laadittiin toimintakykymittarit, joiden avulla oli mahdollista kerätä tietoa toimintaan osallistuneiden henkilöiden toimintakyvystä ja hyödyntää tietoa toimintakyvyn muutosten seurannassa ja arvioinnissa.

Jo kehitettyjen toimintakykymittareiden läpikäyminen osoitti, että saatavilla ei ole useita varta vasten erilaisissa luontoympäristöissä tapahtuvaan luontolähtöiseen toimintaan kehitettyjä mittareita. Koska luonnon hyvinvointivaikutuksia on tutkimuksissa todennettu sekä fyysisen että psykososiaalisen ja myös kognitiivisen toimintakyvyn osa-alueilla (Hirvonen 2014, 16-23), lähtökohtana oli nämä osa-alueet huomioivan mittarin löytäminen. Lisäksi mittarin avulla tuli voida arvioida ja seurata sekä ohjattuun yksilötyöskentelyyn että ryhmätyöskentelyyn osallistuvan henkilön toimintaa.

Kyselylomakkeen muodossa käytettävän toimintakykymittarin keskeinen sisältö rakentui luonnon hyvinvointivaikutuksia käsittelevän tutkimustiedon sekä puutarhaterapeuttisen työskentelyn ryhmätoimintojen arviointiin aiemmin kehitetyn kysymyspatteriston (New York University Medical Center, The Rusk Institute of Rehabilitation Medicine, Horticultural therapy group activity procedure, ks. Wichrowski ym. 1998, 94-95) pohjalta.

Toimintakykymittari räätälöitiin Hoivafarmi-hankkeessa ohjattuun maatilatyöskentelyyn osallistuneiden asiakkaiden toimintaky- vyn arviointiin eikä näin ollen ole sovellettavissa täysin autettavien henkilöiden kanssa laitosympäristössä toteutettavaan luontolähtöiseen toimintaan. Toimintakykylomakkeen voi täyttää joko asiakas itse, asiakkaan työskentelyä ja toimintaa havainnoiva luontolähtöisen toiminnan ohjaaja tai asiakas ja ohjaaja yhdessä.

Lomake on tarkoitus täyttää toimintapäivän lopussa, jolloin kysymyksiin vastataan kyseisen toimintapäivän työskentelyn pohjalta. Lomake sisältää toimintakyvyn neljä osa-aluetta, joiden toteutumista asiakkaan kohdalla arvioidaan 26 väittämällä viisiportaisella asteikolla (taulukko 1).

Yllä kuvatun toimintakyvyn mittarin lisäksi Hoivafarmi-hankkeessa hyödynnettiin varta vasten hankkeen tarpeisiin laadittua arviointilomaketta, jonka ohjaaja täyttää kunkin toimintapäivän jälkeen. Lähtökohtana oli saada käyttöön nopeasti täytettävä seurannan työväline, jossa niin ikään huomioitaisiin toimintakyvyn neljä osa-aluetta: fyysinen toimintakyky, kognitiiviset taidot, sosiaalinen vuorovaikutus sekä mieliala ja tunnetila. Toimintapäivän arviointilomake on muodoltaan numeerinen asteikko asteikolla 1-10, jonka ääriarvoina ovat huono päivä ja hyvä päivä. Numeerisella asteikolla ohjaaja arvioi asiakkaan työskentelyä seuraavilla ulottuvuuksilla:

- tehtävistä suoriutuminen ja työvälineiden käyttö,

- fyysinen jaksaminen työtehtävien aikana,

- ohjeiden vastaanottaminen ja niiden mukaan toimiminen,

- työtehtäviin keskittyminen,

- työskentely ja vuorovaikutus ohjaajan ja muiden ryhmäläisten kanssa sekä

- kiinnostus ja innostuneisuus työskentelyä kohtaan.

Numeerisen arvion lisäksi ohjaaja laatii vapaamuotoisen sanallisen kuvauksen asiakkaan työskentelystä tekemistään havainnoista.

Toimintakykymittari ja ohjaajan arviointilomake käyttöohjeineen annettiin Hoivafarmi-hankkeessa mukana olleille toimijoille. Arviointilomake on otettu käyttöön muun 
Taulukko 1. Hoivafarmi-hankkeessa sovelletun toimintakykymittarin osa-alueet.

\section{Fyysinen toimintakyky}

- Kykenee suoriutumaan kädentaitoja vaativista työtehtävistä.

- Kykenee käyttämään pieniä työvälineitä (esim. oksasakset, käsihara).

- Kykenee suoriutumaan fyysistä voimaa edellyttävistä työtehtävistä (esim. lapiointi).

- Kykenee toimimaan kädet pään yläpuolella.

- Kykenee kantamaan puolen kilon painoisia esineitä.

- Kykenee huomioimaan tehtävien suorittamisessa omat fyysiset rajansa (ei suorita esim. kipua tuottavia ja väärässä asennossa työtehtäviä).

\section{Sosiaalinen vuorovaikutus}

- Puhuu rohkeasti toisten seurassa.

- Aloittaa helposti työskentelyn muiden kanssa.

- Osallistuu mielellään keskusteluun ja yhteistyöhön, kun häntä lähestytään.

- Toimii yhteistyössä muiden ryhmäläisten kanssa.

- Ottaa kontaktia hoidettaviin eläimiin.

- Vastaa asianmukaisesti esitettyihin kysymyksiin.

\section{Kognitiiviset taidot}

- Kykenee seuraamaan sanallisia ja kirjallisia ohjeita.

- Kykenee toimimaan saamiensa ohjeiden mukaisesti.

- Kykenee muistamaan tehtävät ja niiden suorittamisjärjestyksen.

- Suorittaa työtehtävät kärsivällisesti loppuun saakka.

- Kykenee keskittymään työtehtäviin 1 tunnin ajan.

- Kykenee vaihtamaan työtehtävästä toiseen.

- Osaa nimetä työtehtäviin liittyviä työvälineitä, kasveja tai eläimiä.

- Kykenee toimimaan aikataulussa.

- Kykenee selviytymään ongelmatilanteista.

\section{Mieliala ja käsitys itsestä}

- On innostunut ja halukas uusiin työtehtäviin.

- Pyytää apua tarvittaessa.

- Luottaa itseensä työtehtävien tekemisessä.

- Työskentelee periksi antamatta vaikeissakin tehtävissä.

- Kykenee ilmaisemaan tunteitaan rakentavasti ja ilman aggressiivisuutta. muassa yhden hanketoimijan, sosiaalipsykiatrista kuntoutusta ja asumispalvelua mielenterveyskuntoutujille tarjoavan Kotilo ry:n asiakkaiden parissa. Kotilon toiminnassa toimintakyvyn mittareita on tarkoitus hyödyntää maatilalla työskentelevien kuntoutujien alkukartoituksen lisäksi myös toimintakyvyn seurannassa.

Tulosten merkitys: Hoivafarmi-hankkeessa sovellettuja mittareita voidaan käyttää asiakastyössä alkukartoituksessa kuntoutujan työtehtävien suunnittelun tukena sekä asiakkaan toimintakykyä ja sen mahdollisia muutoksia koskevan pitkittäistiedon keräämisessä. Kyselylomakkeen muodossa toteutettavaa toimintakyvyn seurantaa voidaan perustella asiakaslähtöisyydellä ja asiakkaan hyvinvoinnin edistämisellä. Näyttö luontolähtöisen toiminnan asiakasvaikutuksista on palveluntuottajalle keino tehdä palvelun hyö- dyt näkyväksi. Näyttövaade korostunee entisestään, mikäli monituottajuus, yksityinen palvelutuotanto, palvelujen kilpailutus sekä tilaajan ja tuottajan eriyttäminen vahvistuvat käynnissä olevassa sosiaali- ja terveyspalvelu-uudistuksessa.

Avainsanat: green care, luontolähtöinen toiminta, luontohoiva, kuntoutus, toimintakyky, toimintakykymittari

\section{Johanna Hirvonen, FT, YTM, yliopettaja, Kaakkois-Suomen ammattikorkeakoulu \\ Leena Uosukainen, KT, THM, yliopettaja, Kaakkois-Suomen ammattikorkeakoulu}

\section{Lähteet}

Hirvonen J (2014) Luontohoivan asiakasvaikutukset. Mikkelin ammattikorkeakoulu, Julkaisusarja: A 86. Tutkimuksia ja raportteja. WWW-dokument- 
ti: http://urn.fi/URN:ISBN:978-951-588-413-8.

Hirvonen J, Uosukainen L (2015) Luonnon hyvinvointivaikutusten mittaaminen Hoivafarmihankkeessa. Teoksessa A Haapala (toim.) Kestävää hyvinvointia kehittämässä. Painoalan vuosijulkaisu 2015. Mikkelin ammattikorkeakoulu, Julkaisusarja: Vapaamuotoisia julkaisuja. D 65, s.140-145. WWW-dokumentti: http://urn.fi/ URN:ISBN:978-951-588-537-1.

Soini K (toim.) (2014) Luonnosta hoivaa ja voimaa: Miten arvioida Green Care -toiminnan vaikuttavuutta. MTT julkaisuja. WWW-dokumentti: www. mtt.fi/mttkasvu/pdf/mttkasvu21.pdf.

Sámi Soster (2017) Mettäterapia Enontekiöllä. WWWdokumentti: www.samisoster.fi/toiminta/goaikkanas-projekti/mettaterapia. Luettu 10.4.2017.

Valtakunnallinen Green Care Koordinaatiohanke (2017) Green Care -laatumerkkien haku avautui. Tiedote 27.1.2017. WWW-dokumentti: www.gcfinland.fi/tiedostopankki/224/Tiedote-Green-Care-_laatumerkin-haun-avautumisesta-27.1.2017. pdf.

Vedung E (2003) Arviointiaalto ja sen liikkeelle panevat voimat. Helsinki: Stakes, FinSoc Työpapereita $2 / 2003$.

Wichrowski M, Chambers NK, Ciccantelli LM (1998) Stroke, spinal cord and physical disabilities and horticultural therapy practice. Teoksessa SP Simson, MC Straus (toim.) Horticulture as therapy. Principles and practice. Haworth Press, s. 71-104. 